\title{
The Continuing Value of CD4 Cell Count Monitoring for Differential HIV Care and Surveillance
}

Brian Rice ${ }^{1}$, BSc, MSc, PhD; Andrew Boulle ${ }^{2}$, MSc, PhD, MBchB; Sandra Schwarcz ${ }^{3}$, MPH, MD; Amir Shroufi ${ }^{4}$, MPhil, ChB, MB; George Rutherford ${ }^{3}$, AM, MD; James Hargreaves ${ }^{1}$, MSc, PhD

${ }^{1}$ Faculty of Public Health and Policy, Public Health, Environments and Society, London School of Hygiene \& Tropical Medicine, London, United Kingdom

${ }^{2}$ Faculty of Health Sciences, Department of Public Health \& Family Medicine, University of Cape Town, Cape Town, South Africa

${ }^{3}$ Global Health Sciences, University of California San Francisco, San Francisco, CA, United States

${ }^{4}$ Médecins Sans Frontières, Cape Town, South Africa

Corresponding Author:

Brian Rice, BSc, MSc, PhD

Faculty of Public Health and Policy

Public Health, Environments and Society

London School of Hygiene \& Tropical Medicine

15-17 Tavistock Place

London, WC1H 9SH

United Kingdom

Phone: 442079272567

Email: brian.rice@1shtm.ac.uk

\begin{abstract}
The move toward universal provision of antiretroviral therapy and the expansion of HIV viral load monitoring call into question the ongoing value of CD4 cell count testing and monitoring. We highlight the role CD4 monitoring continues to have in guiding clinical decisions and measuring and evaluating the epidemiology of HIV. To end the HIV/AIDS epidemic, we require strategic information, which includes CD4 cell counts, to make informed clinical decisions and effectively monitor key surveillance indicators.
\end{abstract}

(JMIR Public Health Surveill 2019;5(1):e11136) doi: 10.2196/11136

\section{KEYWORDS}

CD4; HIV; differential care; antiretroviral therapy; surveillance; monitoring

The CD4 cell count has been the principal basis for assessing an HIV-infected person's level of immunosuppression and for timing initiation of antiretroviral therapy (ART) [1]. In 2015, the World Health Organization (WHO) recommended starting ART at any CD4 count, regardless of the clinical symptoms or conditions [2]. These guidelines and subsequent studies argue that, for clinical purposes, the frequency of CD4 monitoring post-ART initiation can be reduced or ceased when viral load testing is available and patients are suppressed [2-6].

The move toward universal ART, the expansion of viral load monitoring [7-9], and recommendations to reduce or cease CD4 testing post-ART initiation call into question the value of CD4 testing. Decreased support for CD4 testing could potentially not only result in reduced CD4 monitoring among people who have initiated ART, but also unintentionally lead to reduced quality of monitoring at diagnosis and the period up to ART initiation. In this communication, we highlight the continuing role of CD4 monitoring in guiding clinical decisions and measuring and evaluating the epidemiology of HIV.

The routine collection of CD4 data at diagnosis (baseline) from laboratories and health care facilities (conducting primary or confirmatory HIV tests) continues to provide an assessment of treatment priorities. Importantly, this information remains critical in identifying late diagnosis (as often indicated by a CD4 count of $<350$ cells $/ \mu \mathrm{L}$ ) [10-12]. A late diagnosis indicates that a person is at a significantly elevated risk of HIV-related opportunistic infections and mortality, and has been identified as a primary cause of HIV-related deaths in settings where ART is widely and freely available [10,12-13].

Low CD4 counts are triggers for more intensive follow-up and care in differentiated care models. For example, WHO guidelines on advanced disease recommend that people with a CD4 count $<100$ cells $/ \mu \mathrm{L}$ be screened for cryptococcal disease 
and managed with fluconazole if asymptomatic, those with a CD4 $<200$ cells $/ \mu \mathrm{L}$ receive tailored counselling, and those with a CD4 $<350$ cells $/ \mu \mathrm{L}$ receive cotrimoxazole prophylaxis [14]. It is also recommended that people living with HIV with a count $<100$ cells $/ \mu \mathrm{L}$ be offered the urinary lipoarabinomannan point-of-care test for tuberculosis [14]. In this way, CD4 is facilitating a shift away from symptom-based tuberculosis screening toward an approach of testing all those at high risk of disease. In Uganda, ART-naïve adults with CD4 counts $\leq 250$ cells/ $\mu \mathrm{L}$ are currently screened for tuberculosis and those with CD4 $\leq 100$ cells/ $\mu \mathrm{L}$ are also screened for cryptococcal antigen [15], similar to the case in South Africa [16]. In a recent three-country trial, presumptive antimicrobial treatment in patients initiating ART with CD 4 counts $<100$ cells $/ \mu \mathrm{L}$ resulted in a $30 \%$ reduction in 6 -month mortality [17]. The routine collection and use of CD4 data have also been shown to be cost effective in promoting clinical outcomes such as disability-adjusted life years averted [18,19]. As loss to follow-up is a common outcome along the HIV care continuum [20], it is important that differentiated care models, informed by CD4 monitoring, also consider persons re-engaging in care.

Clinically mediated CD4 monitoring has also been an important feature of HIV surveillance. At the population level, the prevalence of CD4-defined late diagnoses helps monitor the effectiveness of program efforts for early identification [11,21] and is a WHO linkage to care indicator [21]. The linkage of CD4 data at diagnosis with longitudinal CD4 cell counts up to ART initiation has provided important information on trajectories of CD4 depletion between diagnosis and treatment. This information has been used at international, national, and subnational levels to back calculate from the time of diagnosis to the probable time of infection in order to estimate the incidence of HIV [22-26], estimate the prevalence of undiagnosed HIV [24-28], and assign a probable place of infection [29,30].

In a number of settings, the application of CD4-based models and their analyses are either being expanded or newly adopted. In 2016, a new model incorporating CD4 at or after diagnosis, but before ART, was introduced in the United States to estimate HIV incidence, prevalence, and undiagnosed infections [24]. Among European Union member states, a CD4 back-calculation model, which assigns probable place of HIV infection among migrant populations by estimating the time of infection and comparing it with the time of arrival in the host country, is being promoted to inform prevention programs [29,30]. In addition to informing pre-ART care and policy decisions concerning the use of ART for prevention [31], routine CD4 monitoring in South Africa has recently been used to assess the risk of subsequent loss to follow-up from care [32] and to estimate care cascade measures [33]. Although most of the CD4-based activities cited are focused in middle- and high-income settings, the promotion of HIV case surveillance [34] and the collection of CD4 within these systems will hopefully further expand the application of these methods to low- and middle-income settings, including high-prevalence settings in sub-Saharan Africa.
Clinical and surveillance activities relying on CD4 testing will be impaired if testing is reduced or discontinued between diagnosis and ART initiation, or in a setting where viral load testing remains suboptimal. Although it has been suggested that access to viral load monitoring in low-income, high-HIV burden settings may be limited [4], the Joint United Nations Programme on HIV/AIDS in 2016 reported that a number of resource-limited countries have drastically reduced CD4 monitoring in favor of increased viral load testing [35]. In 2018, the President's Emergency Plan for AIDS Relief announced that they will reduce their overall level of support in donor countries for CD4 testing to prioritize viral load testing [36].

Although CD4 monitoring remains essential for the detection and management of HIV-related opportunistic infections such as Cryptococcus, signatories of a 2017 advanced HIV position statement claim donor support for CD4 testing at the primary care level has decreased in recent years [37]. The signatories of this statement included Médecins Sans Frontières. Figure 1 presents ART initiation by CD4 count in a Médecins Sans Frontières treatment program in South Africa. The top bar of the figure suggests an increase in recent years in the number and proportion of people not receiving a CD4 test at the time of treatment initiation. The reduction of CD4 monitoring both at and subsequent to diagnosis has also been brought to the attention of a research team carrying out HIV system assessments in resource-limited settings in 2015 and 2016 (R. Harklerode, personal communication, January 2018) [38].

While highlighting the role of continuing CD4 monitoring in informing clinical and epidemiological activities, we remain fully supportive of the expansion of viral load monitoring. In several areas of clinical management, for example, the monitoring of pediatric HIV infection [39], a combination of CD4 and viral load monitoring is essential. As CD4 tests are more affordable than viral load tests in many countries $[18,19]$ and have already been scaled up, we believe CD4 monitoring presents a model of learning for scaling up optimal and affordable viral load testing.

It is inevitable that the role of CD4 monitoring in guiding clinical decisions will become more selective. However, vigilance and oversight are required to ensure that while we reduce reliance on CD4 monitoring in virologically suppressed patients, we retain our capacity to conduct CD4 testing at diagnosis and up to ART initiation. This remains critically important in diagnosing and treating comorbidities, determining whether a person requires an advanced package of screening and care, reducing mortality, and ensuing the continuity of critical data for surveillance activities (such as estimating HIV incidence and undiagnosed infections). Although we do not advocate for routine CD4 monitoring for all, CD4 should continue to guide the clinical management of persons re-engaging in care or remaining in care but failing treatment. Capacity will preferably be retained at the population level; where this is not the case, representative sampling methods should be considered. To end the HIV/AIDS epidemic, we must obtain essential data to make informed clinical decisions and effectively monitor key surveillance indicators. 
Figure 1. ART initiations in Eshowe and Mbongolwane, KwaZulu-Natal, stratified by CD4 count, 2011 to 2017. CD4 counts are measured as CD4 cells/ $\mu$ L. Q1 was from January to end March 2017. ART: antiretroviral therapy.

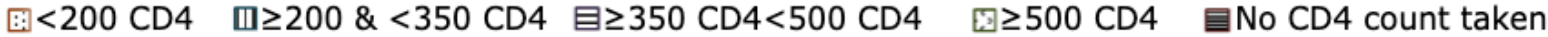

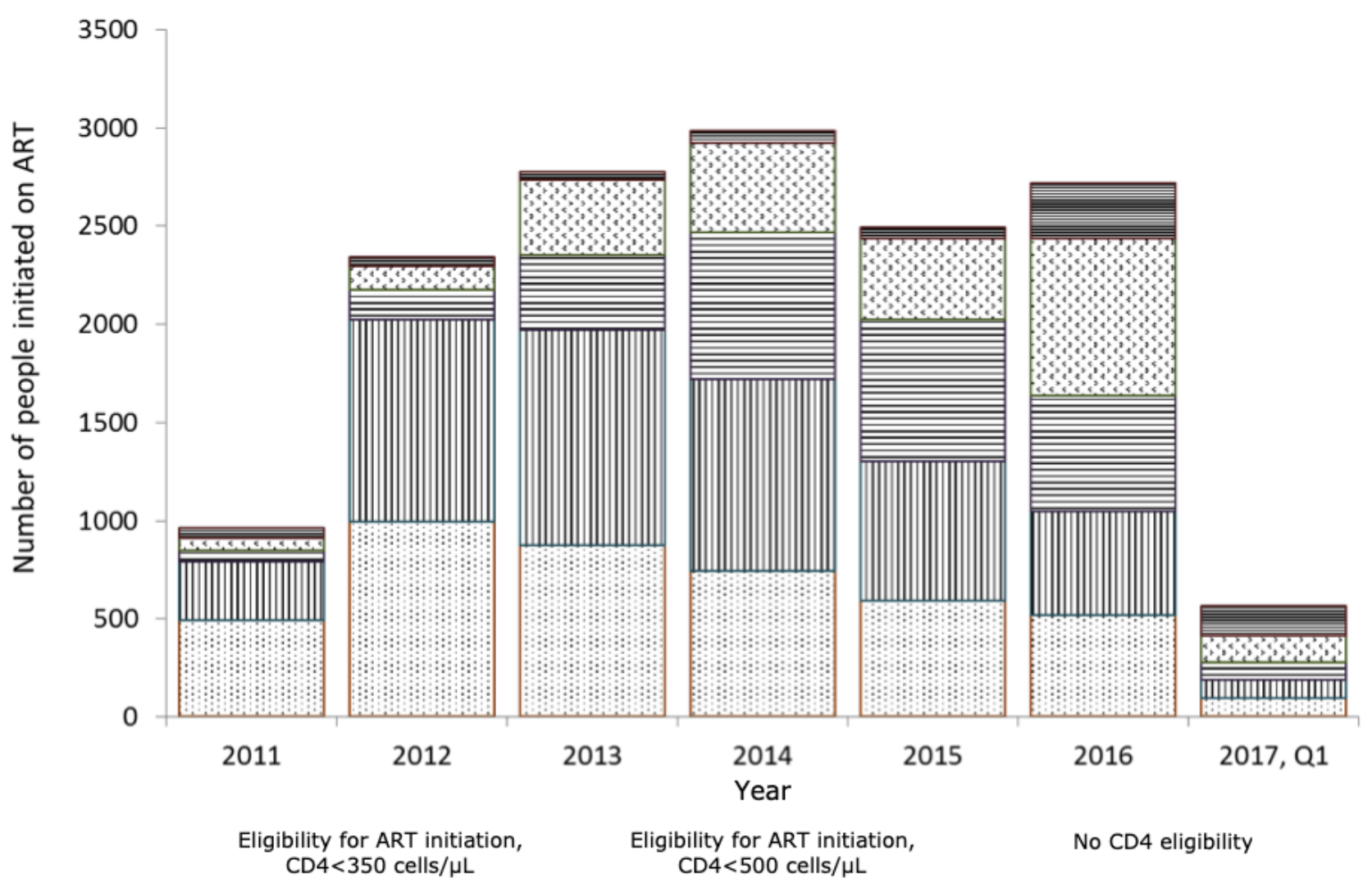

\section{Acknowledgments}

We wish to thank the MeSH Consortium for their support in this work. The MeSH Consortium is funded by the Bill and Melinda Gates Foundation (BMGF-OPP1120138). The views presented in this paper are those of the authors and do not necessarily reflect the views of the BMGF.

\section{Conflicts of Interest}

None declared.

\section{References}

1. World Health Organization. 2010. Antiretroviral therapy for HIV infection in adults and adolescents: recommendations for a public health approach - 2010 revision URL: https://www.who.int/hiv/pub/arv/adult2010/en/ [accessed 2019-02-20] [WebCite Cache ID 76KxkeaYS]

2. World Health Organization. 2015. Guideline on when to start antiretroviral therapyon pre-exposure prophylaxis for HIV URL: https://www.who.int/hiv/pub/guidelines/earlyrelease-arv/en/ [accessed 2019-02-20] [WebCite Cache ID 76Kxmnur2]

3. Davies M, Ford N, Rabie H, Fatti G, Stinson K, Giddy J, et al. Reducing CD4 Monitoring in Children on Antiretroviral Therapy With Virologic Suppression. Pediatr Infect Dis J 2015 Dec;34(12):1361-1364 [FREE Full text] [doi: 10.1097/INF.0000000000000912] [Medline: 26379169]

4. Ford N, Stinson K, Davies M, Cox V, Patten G, Cragg C, et al. Is it safe to drop CD4+ monitoring among virologically suppressed patients: a cohort evaluation from Khayelitsha, South Africa. AIDS 2014 Sep 10;28(14):2003-2005. [doi: 10.1097/QAD.0000000000000406] [Medline: 25102088]

5. Ford N, Meintjes G, Pozniak A, Bygrave H, Hill A, Peter T, et al. The future role of CD4 cell count for monitoring antiretroviral therapy. The Lancet Infectious Diseases 2015 Feb;15(2):241-247. [doi: 10.1016/S1473-3099(14)70896-5] [Medline: 25467647] 
6. Working Group on Modelling of Antiretroviral Therapy Monitoring Strategies in Sub-Saharan Africa, Phillips A, Shroufi A, Vojnov L, Cohn J, Roberts T, et al. Sustainable HIV treatment in Africa through viral-load-informed differentiated care. Nature 2015 Dec 03;528(7580):S68-S76 [FREE Full text] [doi: 10.1038/nature16046] [Medline: 26633768]

7. Cohen M, Chen Y, McCauley M, Gamble T, Hosseinipour M, Kumarasamy N, HPTN 052 Study Team. Prevention of HIV-1 infection with early antiretroviral therapy. N Engl J Med 2011 Aug 11;365(6):493-505 [FREE Full text] [doi: 10.1056/NEJMoa1105243] [Medline: 21767103]

8. Nsanzimana S, Kanters S, Mills E. Towards test and treat strategy for HIV in sub-Saharan Africa. BMJ 2015 Dec 29;351:h6839. [doi: 10.1136/bmj.h6839] [Medline: 26714871]

9. World Health Organization. 2014. Technical and operational considerations for implementing HIV viral load testing: interim technical update URL: https://www.who.int/hiv/pub/arv/viral-load-testing-technical-update/en/ [accessed 2019-02-20] [WebCite Cache ID 76Ky6Pise]

10. Adler A, Mounier-Jack S, Coker R. Late diagnosis of HIV in Europe: definitional and public health challenges. AIDS Care 2009 Mar;21(3):284-293. [doi: 10.1080/09540120802183537] [Medline: 19031304]

11. Antinori A, Coenen T, Costagiola D, Dedes N, Ellefson M, Gatell J, European Late Presenter Consensus Working Group. Late presentation of HIV infection: a consensus definition. HIV Med 2011 Jan;12(1):61-64 [FREE Full text] [doi: 10.1111/j.1468-1293.2010.00857.x] [Medline: 20561080]

12. Rice B, Yin Z, Brown A, Croxford S, Conti S, De Angelis D, et al. Monitoring of the HIV Epidemic Using Routinely Collected Data: The Case of the United Kingdom. AIDS Behav 2017 Jul;21(Suppl 1):83-90. [doi: 10.1007/s10461-016-1604-6] [Medline: 27832390]

13. Mocroft A, Lundgren J, Sabin M, Monforte A, Brockmeyer N, Casabona J, Collaboration of Observational HIV Epidemiological Research Europe (COHERE) study in EuroCoord. Risk factors and outcomes for late presentation for HIV-positive persons in Europe: results from the Collaboration of Observational HIV Epidemiological Research Europe Study (COHERE). PLoS Med 2013;10(9):e1001510 [FREE Full text] [doi: 10.1371/journal.pmed.1001510] [Medline: 24137103]

14. World Health Organization. 2017. Guidelines for managing advanced HIV disease and rapid initiation of antiretroviral therapy URL: http://apps.who.int/iris/bitstream/10665/255884/1/9789241550062-eng.pdf?ua=1 [accessed 2019-02-20] [WebCite Cache ID 76KyGBhIU]

15. Pac L, Horwitz M, Namutebi A, Auerbach BJ, Semeere A, Namulema T, et al. Implementation and operational research: Integrated pre-antiretroviral therapy screening and treatment for tuberculosis and cryptococcal antigenemia. J Acquir Immune Defic Syndr 2015 Apr 15;68(5):e69-e76 [FREE Full text] [doi: 10.1097/QAI.0000000000000527] [Medline: 25761234]

16. Vallabhaneni S, Longley N, Smith M, Smith R, Osler M, Kelly N, et al. Implementation and Operational Research: Evaluation of a Public-Sector, Provider-Initiated Cryptococcal Antigen Screening and Treatment Program, Western Cape, South Africa. J Acquir Immune Defic Syndr 2016 Dec 01;72(2):e37-e42 [FREE Full text] [doi: 10.1097/QAI.0000000000000976] [Medline: 26926942]

17. Hakim J, Musiime V, Szubert A, Mallewa J, Siika A, Agutu C, REALITY Trial Team. Enhanced Prophylaxis plus Antiretroviral Therapy for Advanced HIV Infection in Africa. N Engl J Med 2017 Dec 20;377(3):233-245 [FREE Full text] [doi: 10.1056/NEJMoa1615822] [Medline: 28723333]

18. Kahn J, Marseille E, Moore D, Bunnell R, Were W, Degerman R, et al. CD4 cell count and viral load monitoring in patients undergoing antiretroviral therapy in Uganda: cost effectiveness study. BMJ 2011 Nov 09;343:d6884. [doi: 10.1136/bmj.d6884] [Medline: 22074713]

19. Keebler D, Revill P, Braithwaite S, Phillips A, Blaser N, Borquez A, et al. Cost-effectiveness of different strategies to monitor adults on antiretroviral treatment: a combined analysis of three mathematical models. The Lancet Global Health 2014 Jan;2(1):e35-e43. [doi: 10.1016/S2214-109X(13)70048-2]

20. Keane J, Pharr J, Buttner M, Ezeanolue E. Interventions to Reduce Loss to Follow-up During All Stages of the HIV Care Continuum in Sub-Saharan Africa: A Systematic Review. AIDS Behav 2017 Jun;21(6):1745-1754. [doi:

10.1007/s10461-016-1532-5] [Medline: 27578001]

21. World Health Organisation. 2015. Consolidated strategic information guidelines for HIV in the health sector URL: https:/ /www.who.int/sorry/ [accessed 2019-02-20] [WebCite Cache ID 76KySVO4Q]

22. Birrell P, Chadborn T, Gill O, Delpech V, De Angelis D. Estimating trends in incidence, time-to-diagnosis and undiagnosed prevalence using a CD4-based Bayesian back-calculation. Stat Comm Infect Dis 2012;4(1).

23. Jansson J, Kerr C, Mallitt K, Wu J, Gray R, Wilson D. Inferring HIV incidence from case surveillance with CD4+ cell counts. AIDS 2015 Jul 31;29(12):1517-1525. [doi: 10.1097/QAD.0000000000000679] [Medline: 25870983]

24. Song R, Hall H, Green T, Szwarcwald C, Pantazis N. Using CD4 Data to Estimate HIV Incidence, Prevalence, and Percent of Undiagnosed Infections in the United States. J Acquir Immune Defic Syndr 2017 Dec 01;74(1):3-9. [doi: 10.1097/QAI.0000000000001151] [Medline: 27509244]

25. van Sighem A, Nakagawa F, De Angelis D, Quinten C, Bezemer D, de Coul EO, et al. Estimating HIV Incidence, Time to Diagnosis, and the Undiagnosed HIV Epidemic Using Routine Surveillance Data. Epidemiology 2015 Sep;26(5):653-660 [FREE Full text] [doi: 10.1097/EDE.0000000000000324] [Medline: 26214334] 
26. Szwarcwald C. Estimation of the HIV Incidence and of the Number of People Living With HIV/AIDS in Brazil, 2012. J AIDS Clin Res 2015;06(03):430. [doi: 10.4172/2155-6113.1000430]

27. Lodwick R, Nakagawa F, van Sighem A, Sabin C, Phillips A. Use of surveillance data on HIV diagnoses with HIV-related symptoms to estimate the number of people living with undiagnosed HIV in need of antiretroviral therapy. PLoS One 2015;10(3):e0121992 [FREE Full text] [doi: 10.1371/journal.pone.0121992] [Medline: 25768925]

28. Wong N, Wong K, Lee M, Tsang O, Chan D, Lee S. Estimation of the Undiagnosed Intervals of HIV-Infected Individuals by a Modified Back-Calculation Method for Reconstructing the Epidemic Curves. PLoS One 2016;11(7):e0159021 [FREE Full text] [doi: 10.1371/journal.pone.0159021] [Medline: 27403882]

29. Rice B, Elford J, Yin Z, Delpech V. A new method to assign country of HIV infection among heterosexuals born abroad and diagnosed with HIV. AIDS 2012 Sep 24;26(15):1961-1966. [doi: 10.1097/QAD.0b013e3283578b80] [Medline: 22781226]

30. European Centre for Disease Prevention and Control. 2013. Migrant health: sexual transmission of HIV within migrant groups in the EU/EEA and implications for effective interventions URL: https://ecdc.europa.eu/sites/portal/files/media/en/ publications/Publications/Migrant-health-sexual-transmission.pdf [accessed 2019-02-20] [WebCite Cache ID 76KyfPh0E]

31. McGrath N, Lessells R, Newell M. Time to eligibility for antiretroviral therapy in adults with CD4 cell count $>500$ cells/ $\mu \mathrm{L}$ in rural KwaZulu-Natal, South Africa. HIV Med 2015 Sep;16(8):512-518 [FREE Full text] [doi: 10.1111/hiv.12255] [Medline: 25959724]

32. Grimsrud A, Cornell M, Schomaker M, Fox M, Orrell C, Prozesky H, International Epidemiologic Databases to Evaluate AIDS Southern Africa Collaboration (IeDEA-SA). CD4 count at antiretroviral therapy initiation and the risk of loss to follow-up: results from a multicentre cohort study. J Epidemiol Community Health 2016 Dec;70(6):549-555 [FREE Full text] [doi: 10.1136/jech-2015-206629] [Medline: 26700300]

33. Takuva S, Brown A, Pillay Y, Delpech V, Puren A. The continuum of HIV care in South Africa: implications for achieving the second and third UNAIDS 90-90-90 targets. AIDS 2017 Dec 20;31(4):545-552. [doi: 10.1097/QAD.0000000000001340] [Medline: 28121668]

34. World Health Organisation. 2017. Consolidated guidelines on person-centred HIV patient monitoring and case surveillance Geneva: World Health Organization URL: https://www.who.int/sorry/ [accessed 2019-02-20] [WebCite Cache ID $76 \mathrm{KyqHdPn}]$

35. UNAIDS. 2016. The need for routine viral load testing: questions and answers URL: http://www.unaids.org/sites/default/ files/media asset/JC2845 en.pdf [accessed 2019-02-20] [WebCite Cache ID 76Kyui7Vk]

36. PEPFAR. PEPFAR 2018 Country Operational Plan Guidance for Standard Process Countries URL: https://www.pepfar.gov/ documents/organization/276459.pdf [accessed 2019-02-20] [WebCite Cache ID 76KyxpacA]

37. Medecins sans Frontières. Advanced HIV position statement 2017 URL: https://www.msf.org.za/hiv-position-statement [accessed 2019-02-20] [WebCite Cache ID 76Kz1xlzg]

38. Harklerode R, Schwarcz S, Hargreaves J, Boulle A, Todd J, Xueref S, et al. Feasibility of Establishing HIV Case-Based Surveillance to Measure Progress Along the Health Sector Cascade: Situational Assessments in Tanzania, South Africa, and Kenya. JMIR Public Health Surveill 2017 Jul 10;3(3):e44 [FREE Full text] [doi: 10.2196/publichealth.7610] [Medline: 28694240]

39. U.S. Department of Health and Human Services. Guidelines for the Use of Antiretroviral Agents in Pediatric HIV Infection, 2018 URL: https://aidsinfo.nih.gov/guidelines/html/2/pediatric-arv/59/

clinical-and-laboratory-monitoring-of-pediatric-hiv-infection [accessed 2019-02-20] [WebCite Cache ID 76Kz4eNXo]

\section{Abbreviations}

ART: antiretroviral therapy

WHO: World Health Organization

Edited by S Baral; submitted 25.05.18; peer-reviewed by J Todd, S Xueref; comments to author 23.09.18; revised version received
19.10.18; accepted 02.11.18; published 20.03 .19
Please cite as:
Rice B, Boulle A, Schwarcz S, Shroufi A, Rutherford G, Hargreaves J
The Continuing Value of CD4 Cell Count Monitoring for Differential HIV Care and Surveillance
JMIR Public Health Surveill 2019;5(1):e11136
URL: $\underline{\text { http://publichealth.jmir.org/2019/1/e11136/ }}$
doi: $\underline{10.2196 / 11136}$
PMID: $\underline{30892272}$


(CBrian Rice, Andrew Boulle, Sandra Schwarcz, Amir Shroufi, George Rutherford, James Hargreaves. Originally published in JMIR Public Health and Surveillance (http://publichealth.jmir.org), 20.03.2019. This is an open-access article distributed under the terms of the Creative Commons Attribution License (https://creativecommons.org/licenses/by/4.0/), which permits unrestricted use, distribution, and reproduction in any medium, provided the original work, first published in JMIR Public Health and Surveillance, is properly cited. The complete bibliographic information, a link to the original publication on http://publichealth.jmir.org, as well as this copyright and license information must be included. 